\title{
Pengambilan Keputusan Klinis Berdasarkan Intuisi Perawat
}

\author{
Natasia Atania Sitepu \\ natasiaatania2@gmail.com
}

\section{Latar Belakang}

Perawat dalam praktik klinis harus sering membuat keputusan kritis dalam kondisi yang sangat kompleks dan tidak pasti. Keputusan harus dibuat dengan benar dan sering dengan data yang tidak lengkap, bertentangan, atau ambigu. Kondisi seperti itu menuntut perawat tidak hanya mengembangkan keterampilan analitis yang ketat tetapi juga mengakui penggunaan intuisi dalam membuat keputusan klinis. Dalam beberapa tahun terakhir, disiplin keperawatan telah menunjukkan peningkatan kemauan untuk mengeksplorasi berbagai pola pengetahuan, termasuk empiris, estetika, etika, pengetahuan pribadi, dan pengetahuan yang terhubung. Kesadaran intuitif diakui sebagai komponen refleksi diri, proses mencari ke dalam yang memandu perawat dan klien mereka "menuju penyembuhan, harmoni, dan kesejahteraan"

Intuisi didefinisikan sebagai penerapan pengetahuan atau pemahaman yang disengaja yang diperoleh segera secara keseluruhan dan yang secara independen berbeda dari proses penalaran biasa, linier, dan analitis. Diterapkan pada situasi klinis, intuisi adalah komponen penilaian kompleks, tindakan memutuskan apa yang harus dilakukan dalam situasi yang membingungkan, seringkali ambigu dan tidak pasti. Ini adalah tindakan mensintesis pengetahuan empiris, etika, estetika, dan pribadi. Dengan kata lain, penilaian intuitif adalah keputusan untuk bertindak atas dasar kesadaran tiba-tiba dari pengetahuan yang terkait dengan pengalaman sebelumnya, dipersepsikan secara keseluruhan, dan sulit untuk diartikulasikan.

Pertimbangan klinis dan pengambilan keputusan pada perawat berpengalaman terkait dengan pengetahuan yang kompleks dan kemampuan untuk menanggapi isyarat yang berubah dengan cepat dalam lingkungan yang tidak pasti. Masters menegaskan bahwa semua keputusan melibatkan risiko dan menemukan bahwa keputusan keperawatan dipengaruhi oleh kecenderungan seseorang untuk mengambil risiko. Mereka juga menemukan bahwa perawat memiliki pengambilan risiko yang lebih tinggi daripada populasi umum. Proses pengambilan 
keputusan yang digunakan oleh perawat untuk memilih, mengumpulkan, dan menggunakan informasi untuk membuat penilaian tentang status kesehatan pasien tidak terstruktur, berbeda dengan penilaian dari kepala hingga kaki yang diikuti dalam pemeriksaan fisik yang khas. Selain itu, perawat menghadapi dilema etika dalam praktik klinis ketika mengakui intuisi mereka membawa mereka ke keputusan yang berbeda dari yang dicapai hanya dari data empiris atau konkret, atau ketika mereka tidak dapat bertindak berdasarkan penilaian tersebut karena batasan peran profesional.

Intuisi sebagai keterampilan kognitif yang menyintesis dan kreatif, sangat dibutuhkan dalam kelompok yang cenderung terlalu banyak menggunakan kecerdasan dan aspek analitis dari pikiran. Teori intuisi Bastick mengakui pentingnya kreativitas atau kemampuan untuk melihat solusi sebagai asosiasi yang tidak biasa antara ide atau hal. Bastick juga menegaskan bahwa pengalaman sebelumnya dikaitkan dengan wawasan dan bahwa proses intuitif melibatkan seluruh tubuh dalam integrasi fakta ke dalam pemahaman yang bermakna tentang suatu situasi atau masalah.

George \& Dane (2016) menambahkan bahwa studi mengenai pengambilan keputusan yang melibatkan intusi serta emosi sebaiknya dilakukan dipenelitian mendatang. Hal ini lantaran ada kelangkaan penelitian terdahulu mengenai pengambilan keputusan berdasarkan intuisi (Elbanna \& Fadol, 2016). Sehingga dengan situasi seperti ini pengambilan keputusan berdasarkan intuisi terkait kreatifitas serta inovasi yang dilakukan oleh perawat sangat dibutuhkan.

Penelitian mengenai pengambilan keputusan berdasarkan intuisi ini juga penting dilakukan di Indonesia lantaran penelitian dengan topik serupa hampir belum pernah dilakukan di Indonesia, hal ini dapat ditinjau melalui lampiran data base di Google Scholar atau Google Cendikia dengan rentang waktu dari tahun 2015-2019 menunjukkan bahwa penelitian terkait pengambilan keputusan di Indonesia masih sangat general dan belum terfokus pada aspek intuisi.

\section{Metode}

Metode yang digunakan dalam penulisan ini adalah metode kualitatif yang dimana penulis mengumpulkan data sebanyak-banyaknya untuk dianalisis. Tulisan ini didasarkan dengan menganalisis berbagai jurnal atau karya tulis ilmiah yang berfokus pada "Intuisi dalam 
Pengambilan Keputusan Keperawatan”. Adapun tinjauan literatur yang digunakan dalam penulisan ini menggunakan metode kajian bebas terhadap pokok bahasan yang dikumpulkan dari jurnal atau karya tulis ilmiah yang bersal dari E-book atau Google Scholar. Pengolahan ini dilakukan dengan metode membandingkan beberapa jurnal atau karya tulis ilmiah yang digunakan dan berhubungan dengan pengambilan keputusan berdasarkan intuisi.

\section{Hasil}

Telah ada banyak upaya untuk memahami bagaimana perawat dapat mengambil keputusan yang efektif. Untuk memiliki kinerja pengambilan keputusan yang positif dalam segala situasi, perawat harus merespon secara tepat dengan menggunakan sistem pemrosesan informasi kognitif mereka. Perawat juga harus membuat keputusaan dengan informasi yang tersedia bagi mereka pada titik waktu tertentu.

Pendidik keperawatan telah menekankan peran berpikir kritis dalam penilaian klinis, tetapi intuisi juga dapat menjadi alat yang berharga dalam pengaturan klinis. Keterampilan berpikir kritis harus memfasilitasi penalaran logis tentang kasus klinis dan diterjemahkan ke dalam peningkatan kompetensi klinis, meskipun bukti untuk hubungan langsung ini beragam (Brunt 2005). Penelitian ekstensif pada model statistik dari penilaian klinis telah menunjukkan rumus matematika seringkali lebih akurat daripada intuisi manusia (Dawes et al. 1989). Namun, penelitian tentang penilaian dan pengambilan keputusan telah menunjukkan bahwa intuisi dan analisis adalah strategi kognitif yang berharga dan kesesuaiannya bergantung pada faktor-faktor seperti kompleksitas tugas dan tingkat pengalaman (Hammond et al. 1987, Klein 1998, Pretz 2011).

Intuisi lebih dari sekadar "firasat", itu adalah proses yang didasarkan pada pengetahuan dan pengalaman perawatan dan memiliki tempat di samping bukti berbasis penelitian. Perawat mengintegrasikan intuisi, analisis, dan sintesis di samping data objektif saat membuat keputusan. Mereka harus mengandalkan intuisi dan menggunakan pengetahuan ini dalam praktik klinis sebagai pendukung dalam pengambilan keputusan, yang meningkatkan kualitas dan keamanan perawatan pasien.

Ide utama dari teori proses ganda adalah bahwa analisis dan intuisi tidak boleh dilihat sebagai dua jenis kognisi yang terpisah, melainkan sebagai titik akhir pada skala geser di mana 
kognisi mencakup analisis dan intuisi. Ini memotivasi pengambilan keputusan manusia dan membedakan antara proses tidak sadar, cepat dan refleksif (misalnya memori asosiatif) dan penalaran analitis sadar yang dapat memodifikasi atau memblokir reaksi tak sadar.

\section{Pembahasan}

Pengambilan Keputusan

Proses pengambilan keputusan klinis merupakan komponen penting dalam proses keperawatan (Diana Catarina, 2009), sehingga dibutuhkan kemampuan perawatan karena Keterbatasan pengetahuan dan kemampuan yang dimiliki perawat dapat menghambat perawat dalam mengambil keputusan mengenai perawatan yang akan diberikan kepada klien yang akan berakibat fatal terhadap klien (Kozier et al, 2010).

Keputusan klinis adalah suatu proses yang meliputi diagnosis klinis, penilaian dan keputusan tentang apa yang harus dilakukan (Ennis 1996). Proses pengambilan keputusan dalam praktik klinik keperawatan dipahami sebagai serangkaian keputusan yang dibuat oleh perawat dalam interaksinya dengan pasien mengenai jenis pengamatan yang akan dilakukan dalam situasi yang di alami klien (pengkajian keperawatan), perumusan diagnosa keperawatan, rencana tindakan keperawatan yang harus diambil, tindakan keperawatan yang akan diambil serta evaluasi (Dianan Catarina. 2009, Jan Florin. 2007, Mehee, 2014).

Pengambilan keputusan yang tepat menggunakan suatu pendekatan yang sistematis terhadap hakekat suatu masalah dengan pengumpulan fakta-fakta dan data. Dalam menentukan alternatif yang matang untuk mengambil suatu tindakan yang tepat didasarkan pada kriteria tertentu atas dua atau lebih alternatif yang sesuai (George R. Terry, 2019). Pengambilan keputusan dalam penyelesaian masalah membutuhkan kemampuan yang mendasar bagi praktisi kesehatan, khususnya dalam asuhan keperawatan (Dolan, 2017). Pengambilan keputusan tidak hanya berpengaruh pada proses pengelolaan asuhan keperawatan, tetapi penting untuk meningkatkan kemampuan merencanakan perubahan. Perawat pada semua tingkatan posisi klinis harus memiliki kemampuan menyelesaikan masalah dan mengambil keputusan yang efektif, baik sebagai pelaksana/staf maupun sebagai pemimpin (Dolan, 2017; Nursalam, 2014). 
Pengambilan keputusan sangat penting keberadaannya dalam asuhan maupun dalam manajemen keperawatan. Pengambilan keputusan merupakan suatu proses yang mencakup semua penilaian kegiatan yang diperlukan guna membuktikan dan meperlihatkan pilihan terbaik dalam menyelesaiakan suatu masalah tertentu. Setiap keputusan adalah akibat dari sebuah proses dinamis yang dipengaruhi oleh banyak kekuatan, pengambilan keputusana bukan merupakan prosedur yang tetap akan tetapi sebuah proses yang beruntun. pengambilan keputusan adalah proses yang melibatkan pendekatan sistemik yang harus diadaptasikan dengan lingkungan.

Kegiatan pengambilan keputusan pada prinsipnya meliputi setidaknya empat aktivitas, Aktivitas yang pertama adalah kegiatan inteligensi. Kegiatan inteligensia di sini merupakan kegiatan mengamati lingkungan untuk kepentingan membuat keputusan. Kedua, kegiatan perancangan. Kegiatan menemukan, mengembangkan dan analisis berbagai kemungkinan tindakan dalam rangka pembuatan keputusan. Ketiga, kegiatan pemilihan, yaitu kegiatan memilih atau menentukan tindakan tertentu dari berbagai alternative tindakan yang dapat diambil. Terakhir, keempat, kegiatan peninjauan. Tindakan yang telah dipilih kemudian dilaksanakan dan dievaluasi. Bila proses pengambilan keputusan dianalisis, maka analisis tersebut sebenarnya tidak jauh berbeda dengan analisis proses kebijakan.

Intuisi

Menurut Sinclair, Ashkanasy, \& Chattopadhyay (2010) intuisi didefinisikan sebagai pengetahuan langsung yang dihasilkan oleh pemrosesan informasi holistik tanpa sadar dan cenderung mempengaruhi kognisi. Sedangkan pengambilan keputusan intuisi diartikan sebagai pengambilan keputusan yang bergantung pada kecepatan pengenalan pola dan asosiasi tak sadar untuk menghasilkan penilaian secara afektif yang mana hal ini berkaitan dengan penggunaan pengalaman (Marinos \& Rosni, 2017). Erenda, Dd, Meško, \& Bukovec (2014) menyebutkan bahwa pengambilan keputusan intuitif pada dasarnya dipengaruhi oleh kecerdasan emosional, gaya pengambilan keputusan serta kompetensi kepemimpinan.

Hasil penelitian Dane dan Pratt (Sukmana, 2011) menyebutkan bahwa setidaknya intuisi berperan dalam tiga aspek berikut, yaitu (1) sebagai sarana untuk pemecahan masalah, (2) sebagai masukan untuk membuat keputusan moral, dan (3) sebagai instrumen untuk memfasilitasi 
kreatifitas. Sedangkan Rorty (1967, dalam Dane dan Pratt, 2007) memandang intuisi bukan sebagai proses tetapi sebagai hasil dari suatu proses yang unik. Dia mendefinisikan intuisi sebagai immediate apprehension yang mengarah pada pertimbangan subyektif seseorang dalam memahami suatu fakta atau memecahkan suatu masalah. Sehingga, seseorang bisa menggunakan intuisi sebagai jembatan untuk mencari solusi dari suatu permasalahan yang dihadapi dalam pemecahan masalah. Dengan demikian, intuisi ikut berperan dalam kegiatan pemecahan masalah.

Selain intuisi dalam pemecahan masalah, Dane \& Pratt (Sukmana, 2011) juga menyebutkan intuisi lain, yaitu adanya intuisi kreatif, dimana intuisi kreatif merupakan perasaan yang muncul ketika pengetahuan dikombinasikan dengan sesuatu yang baru. Intuisi kreatif ini merupakan intuisi yang mendukung tingkat berpikir kreatif seseorang. Dengan demikian, intuisi memiliki peranan dalam tingkat berpikir kreatif dimiliki seseorang ataupun sebaliknya.

Pengambilan Keputusan Klinis Berdasarkan Intuisi Perawat

Karakteristik yang dapat membantu peningkatan pemahaman intuisi perawat dalam praktik klinis, dalam hubungan, dan dalam proses keperawatan menggambarkan perspektif yang berbeda bahwa intuisi berperan dalam lebih atau kurang semua langkah proses keperawatan. Proses keperawatan adalah model pengambilan keputusan induktif yang berasal dari perspektif rasionalis dimana pemecahan masalah adalah fokusnya. Perawat yang lebih terbuka dan reseptif terhadap refleksi dan yang mengikuti firasat mereka dalam proses keperawatan juga tampaknya menemukan pola dan petunjuk tak terduga yang memandu tindakan dan pengambilan keputusan mereka. Mereka juga memvalidasi keputusan mereka berdasarkan intuisi dalam hubungannya dengan data objektif konkret seperti fakta ilmiah, tanda-tanda vital, dan tes darah.

Proses keperawatan sebagai sebuah konsep harus dikembangkan dan harus mencakup pengetahuan tentang intuisi dan analisis, menurut Miller dan Rew. Menurut Chilcote (2016) pengetahuan holistik diperoleh melalui sintesis dan bukan analisis. Simmons mengemukakan bahwa intuisi adalah salah satu dari beberapa atribut penalaran klinis ketika membuat evaluasi dan keputusan. Pengetahuan intuitif terutama berfokus pada pemahaman, sedangkan analisis linier berfokus pada menemukan jawaban yang benar. King dan Appleton berpendapat bahwa kemampuan perawat untuk merefleksikan keputusan masa lalu juga dapat meningkatkan 
kemampuan mereka untuk membuat penilaian intuitif. Situasi perawatan yang mengarah pada penilaian dan keputusan intuitif bergantung pada beberapa faktor yang perawat sendiri, dalam banyak kasus, tidak dapat atau tidak dapat mempengaruhi, menurut Thompson dan Dowding. Ini mungkin karena anggapan bahwa intuisi adalah semacam strategi koping bagi perawat untuk mengelola, mengatur, dan bertindak misalnya dalam situasi perawatan yang kompleks dengan pasien sekarat yang memerlukan intuisi atau analisis. Pendekatan dalam proses keperawatan menuntut agar penilaian dan keputusan menjadi dasar untuk analisis atau intuisi. Pretz dan Folse di sisi lain berarti bahwa mungkin untuk menggabungkan intuisi dan analisis sebagai proses paralel.

Teori kontinum kognitif (CCT) (Hammond 1988), bertujuan untuk menyatukan intuisi dan analisis untuk bekerja sama dan sebagai komponen dari proses keperawatan dalam pengambilan keputusan, dan memungkinkan penilaian yang akurat. CCT terstruktur dan sistematis dan seperti yang disarankan oleh Standing (2008), CCT membantu perawat untuk mengembangkan keterampilan analitik mereka dan meningkatkan kesadaran tentang, misalnya informasi dan petunjuk yang menyesatkan untuk meningkatkan keselamatan pasien. Intuisi tampaknya paling berguna dalam kasus situasi perawatan klinis yang kompleks dan disarankan agar tidak ada kontradiksi antara intuisi dan analisis. Pretz dan Folse (2010) berpendapat bahwa strategi penalaran yang berbeda yang dibutuhkan oleh intuisi dan analisis memastikan kualitas pengambilan keputusan. Pilihan keputusan mungkin benar atau salah, dan setiap keputusan mengandung tanggung jawab, tetapi juga konsekuensi, menurut Simmons (2010).

Perawat yang lebih berpengalaman tampaknya memiliki kepercayaan yang lebih besar dalam penilaian intuitif mereka yang sejalan dengan Pretz dan Folse (2010). Hubungan antara perawat dan pasien juga penting untuk membuat penilaian intuitif. Smith dkk. (2004) mengemukakan bahwa kontak antara perawat dan pasien penting bagi perawat untuk mendeteksi perubahan kondisi pasien. Perawat yang terbuka dan reseptif untuk memfasilitasi penggunaan intuisinya menjelaskan bagaimana hal ini memungkinkan mereka untuk mengamati dan memeriksa tanda dan gejala pasien di luar cakupan gejala yang diungkapkan oleh pasien. Hasil dari hal ini dapat berarti bahwa masalah pasien ditemukan lebih awal yang berpotensi dapat memberikan hasil yang positif dan meningkatkan keselamatan pasien. 
Kualitas pribadi penting untuk mengembangkan rasa intuisi dan perawat intuitif yang dapat diakses secara emosional, terbuka dan rentan juga semakin terlibat secara emosional dengan pasien mereka. Melalui kualitas pribadi, kemampuan untuk merefleksikan, lahir dari pengalaman, juga mengubah pengetahuan intuitif perawat tentang proses keperawatan, menurut Rew dan Barrow (1989, 2007). Hams (2000) berpendapat bahwa pengalaman intuisi memandu perawat untuk mengambil tindakan bagi pasien.

\section{Penutup}

Intuisi perawat merupakan komponen penting dalam kaitannya dengan perawatan pasien dan memandu perawat dalam proses keperawatan. Intuisi dalam keperawatan juga merupakan bagian penting dari pengambilan keputusan klinis yang efektif yang mendukung perawatan pasien yang aman. Pengetahuan, pengalaman, tingkat keterampilan, karakteristik pribadi, dan hubungan dengan pasien semuanya memainkan peran penting dalam kemampuan perawat untuk mengembangkan dan menerapkan kemampuan intuitif mereka, tetapi beberapa pengaturan perawatan kesehatan mungkin mencegah penggunaan intuisi. Intuisi dianggap kurang efektif bila perawat tidak mengalami kesejahteraan pribadi, yang berdampak negatif pada pasien, sebagai esmen dan pengambilan keputusan. Perawat mengintegrasikan intuisi dan analisis atau sintesis bersama data objektif saat membuat keputusan. Mereka harus waspada terhadap intuisi mereka, yang pada gilirannya dapat memperluas pengetahuan dan pengalaman mereka dan karenanya dapat meningkatkan kualitas perawatan pasien.

\section{Daftar Pustaka}

Amelia, r., R., \& Afriansyah, H. (2019, June 29). Dasar Pengambilan Keputusan

APRILIANIKA, L. N., \& PERDHANA, M. S. (2019). ANALISIS FAKTOR YANG MEMPENGARUHI PENGAMBILAN KEPUTUSAN BERDASARKAN INTUISI (Studi Pada Pengusaha Sektor UKM Bidang Usaha Kuliner Kota Bojonegoro, Jawa Timur) (Doctoral dissertation, Fakultas Ekonomika dan Bisnis). 
ARIEF A, A., \& ADI WIBOWO, A. S. (2010). Peran Laporan Keuangan dan Intuisi dalam Pengambilan Keputusan Kredit (Studi Empiris pada Perbankan Kota Semarang) (Doctoral dissertation, UNIVERSITAS DIPONEGORO).

Gani, A. N., Rofi'i, M., \& Maksum, I. (2019). Efek sistem pemrosesan informasi rasional dan intuitif pada pengambilan keputusan kewirausahaan: sebuah tinjauan literatur. Jurnal Ekonomi Modernisasi, 15(3), 149-161.

Lestari, M. (2019). IMPLEMENTASI MODEL PEMBELAJARAN BERBASIS INTUISI TERHADAP KREATIFITAS SISWA. Jurnal Pendidikan Matematika, 2(1).

Melin-Johansson, C., Palmqvist, R., \& Rönnberg, L. (2017). Clinical intuition in the nursing process and decision-making-A mixed-studies review. Journal of clinical nursing, 26(23-24), 3936-3949.

Pashar, I., \& Dwiantoro, L. (2020). Pengaruh Empowerment Terhadap Pengambilan Keputusan Perawat: Kajian Literature Review. Journal of Holistic Nursing Science, 7(2), 124-132.

Pretz, J. E., \& Folse, V. N. (2011). Nursing experience and preference for intuition in decision making. Journal of clinical nursing, 20(19-20), 2878-2889.

Rahayu, C. D., \& Mulyani, S. (2020). Pengambilan Keputusan Klinis Perawat. Jurnal Ilmiah Kesehatan, 10(1), 1-11.

Rew, L. (2000). Acknowledging intuition in clinical decision making. Journal of holistic nursing, 18(2), 94-108.

Sa'o, S. (2020). INTUISI SEBAGAI SALAH SATU SOLUSI MERAIH PRESTASI BELAJAR MATEMATIKA. Jurnal Magister Pendidikan Matematika (JUMADIKA), 2(1), 28-33.

Simamora, R. H. (2005). Hubungan Persepsi Perawat Pelaksana Terhadap Penerapan Fungsi Pengorganisasian Yang Dilakukan Oleh Kepala Ruangan Dengan Kinerjanya Diruang Rawat Inap RSUD Koja Jakarta Utara (Doctoral dissertation, Tesis FIK UI, Tidak dipublikasikan).

Simamora, R. H. (2019). Menjadi perawat yang: CIH'HUY. Surakarta: Kekata Publisher. 
Wardani, D. A. (2020). PENGARUH PENDIDIKAN KESEHATAN DENGAN MEDIA AUDIO VISUAL TER-HADAP PENGAMBILAN KEPUTUSAN INTUITIF METODE KONTRASEPSI JANGKA PANJANG. Jurnal Medika: Karya Ilmiah Kesehatan, 5(1). 